\title{
PENGARUH INTENSI TURNOVER DAN KETIDAKHADIRAN TERHADAP KINERJA PEGAWAI DINAS PENDIDIKAN DKI JAKARTA
}

\begin{abstract}
Mutiara Annisa Fitri*
Abstract: The research was conducted to teachers education office of DKI Jakarta. By using a survey method with path analysis applied in testing hypothesis the number 52 employee as sample was selected by using Slovin formula. Based on the results of data analysis in this research it is concluded: (1) the turnover intention have negative direct effect to job performance; (2) the absenteeism have negative direct effect to job performance; (3) the turnover intention have positif direct effect to absenteeism. The job performance can be improved through reduction of turnover intention and absenteeism
\end{abstract}

Keywords: Job Performance, turnover intention, and absenteeism

\section{PENDAHULUAN}

Dinas pendidikan menjadi lembaga dimana semua program terpusat yang senantiasa diikuti oleh program-program sekolah meskipun pada era saat ini sudah memasuki sistem otonomi daerah. Lembaga sekolah diberikan kebebasan dalam menjalankan tugas dan fungsinya sebagai lembaga untuk mengembangkan sumber daya manusia, akan tetapi, semua lembaga sekolah tidak bisa serta merta melepaskan diri dari kebijakan yang dibuat oleh Dinas Pendidikan setempat.

Melihat fenomena tersebut, maka Dinas Pendidikan harusnya memiliki pegawai yang mampu dipercaya serta memiliki kapabilitas untuk melaksanakn tugas dan fungsinya sebagaimana yang telah dimanatkan kepada mereka masing masing sebelumnya.

Hal tersebut merupak sebuah tantangan yang dihadapi oleh Dinas Pendidikan setempat, dimana harus dituntut untuk menepatkan seseorang sesuai dengan kemampuannya (the right man and the right place), akan tetapi Dinas pendidikan kesulitas dalam memenuhi kebutuhan tersebut meskipun hal tersebut akan membentu pegawai dalam meningkatkan kinerjanya.

Di samping itu, pimpinan lembaga juga kesilitas dalam menghadapi tindakan pegawai yang semakin hari semakin menjadi, mulai dari tingginya ketidakhadiran yang semakin hari semakin meningkat, keinginan pegawai untuk keluar dari tempat kerja semakin tinggi dengan berbaai macam alasan, misalnya adanya lapangan kerja baru yang lebih menjanjikan, persoalan rendahnya reward yang diterima dan lain sebagainya.

Pimpinan lembaga akan kesulitan dalam mencari pegawai baru untuk menggantikan posisi pegawai yang meninggalkan tempat kerja atau keluar dari tempat kerja, di samping itu, lembaga juga akan mengalami kerugian dalam hal

* Asisten Dosen Universitas Muhammadiyah Makassar 
tenaga, waktu dan finansia, mencari pegawai yang sesuai dengan posisi yang dibutuhkan agak sulit, di sisi lain pegawai baru juga harus mendapatkan pelatihan agar mampu memahami apa yang akan menajadi tugas dan fungsinya.n. " Maka dari itu peneliti ingin mengkaji secara ilmiah apakah turnover dan ketidakhadiran berpengaruh terhadap kinerja.

Menurut Greene (2011:29), "the first guiding principle of performance management is to define performance in a manner that fits the organization's context a objectives. The definition of performance must also enable an organization to measure results and to compare the actual results to what is required. And performance must be defined and managed in a way that is viewed as fair and appropriate by employees, as well as by other parties at interest. Perfofrnance management is a major component of the psychological contract, entered into by the employer and the employees. If the empl ${ }^{\circ}$ yer efmes performance using criteria that are unacceptable to employees, or if the employer sets standards that are viewed as unreasonable by employees, there will be conflict".

Prinsip pertama dari manajemen kinerja adalah untuk menentukan kinerja dengan cara yang sesuai dengan konteks dan tujuan organisasi. Definisi kinerja juga harus mengaktifkan sebuah organisasi untuk mengukur hasil dan membandingkan hasil aktual dengan apa yang dibutuhkan. Kinerja harus didefinisikan dan dikelola dengan cara yang dipandang adil dan tepat oleh pegawai, maupun oleh pihak lain yang berkepentingan. Kinerja manajemen merupakan komponen utama dari kontrak psikologis yang dibuat oleh pemberi kerja dan pegawai.Jika pimpinan mendefinisikan kinerja menggunakan kriteria yang tidak dapat diterima pegawai, atau jika pimpinan menetapkan standar yang dipandang tidak masuk akal oleh pegawai, akan ada konflik. Ini berarti diperlukan keseragaman persepsi antara pimpinan dengan pegawai.

Menurut Johnson (2009:341) kinerja dapat didefinisikan dari dua perspektif, yakni kinerja sebagai perilaku dan hasil.Kinerja sebagai perilaku, antara lain didefinisikan oleh Rotundo dan Sackett sebagaimana dikutip Catherine sebagai berikut, "job performance is typically conceptualized as actions and behaviors that are under the control of the individual that contribute to the goals of the organization". Kinerja biasanya dikonseptualisasikan sebagai tindakan dan perilaku yang berada di bawah kendali individu yang berkontribusi terhadap tujuan organisasi.

Bagi Sharma (2008:02), "job performance was defines in terms of rise inthe level of output of services with the same or reduced level of input as a result of better work methods and improved technology". Kinerja didefinisikan sebagai istilah kenaikan tingkat pelayanan dengan tingkat yang sama atau dikurangi dari masukan sebagai hasil dari metode kerja yang lebih baik dan peningkatan teknologi.

Pendapat serupa didefinisikan oleh Jex (2002:100) bahwa, "Job performance is behavior, so job performance is rarely measured directly. Meore typically, what is measured, is some external assessment of job performance. According to Murphy (1989a), performance can be assessed in eight different ways: (1) paper/pencil tests; (2) job skills tests; (3) on-site hands-on testing; (4) off-site hands-on testing; (5) high-fidelity simulations; (6) symbolic simulations; (7) task ratings, and (8) global ratings. By far, the two most common methods of 
performance assessment in organizations are ratings of employees' performance on specific tasks, and ratings of overall performance on the job". Pendapat yang berbeda dikemukakan oleh Laitinen (2002:66) bahwa,"job performance is the ability of an object to produce results in a dimension determined a priori, in relation to a target". Kinerja adalah kemampuan sebuah objek untuk memproduksi hasil dalam sebuah dimensi yang telah ditentukan sebelumnya dalam hubungan terhadap suatu target.

Pengertian kinerja juga dinyatakan oleh Daft (2010:08), "performance is the organization's ability to attain its goals by using resources in an efficient and effective manner". Kinerja adalah kemampuan organisasi untuk mencapai tujuannya dengan menggunakan sumber daya secara efisien dan efektif. Menurut Robbins dan Cuolter (2012:492), "perfomance is all of these things it's the end result of an activity". Kinerja adalah semua hal dan itu merupakan hasil akhir dari semua kegiatan.

Byrs dan Rute (2008:216) mengemukakan bahwa, "performance of a task completion rate of employees who demonstrate achievement incompleting the work". Kinerja merupakan tingkat penyelesaian tugas yang menunjukkan pencapaian pegawai dalam menuntaskan pekerjaan.

Pengertian kinerja juga dinyatakan oleh Bernardin (2007:135), "performance is a record of results generated from a particular job function activity during a specific time period". Kinerja adalah catatan yang dihasilkan dari fungsi suatu pekerjaan tertentu atau selama periode waktu tertentu. Sejalan dengan pernyataan Benardin tersebut, Wilkinson dan Redman (2003:63) mendefinisikan, "performance an output or the output of a series of activities carried out in a tematic and planned productivity gains as well as the final results for organization or company". Kinerja atau unjuk kerja sebagai outputdari serangkaian kegiatan yang dilakukan secara sistematis dan terencana yang menghasilkan produktivitas serta hasil dari keuntungan bagi organisasi atau perusahaan.

Dalam melihat kinerja pegawai perlu terlebih dahulu ditetapkan standar kinerja atau indikator kinerja yang akan digunakan sebagai parameter untuk menilai kinerja. Menurut Wibowo (2007:323), “ukuran kinerjamerupakan alat ukur yang harus bersifat objektif, sehingga diperlukan adanya kriteria yang sama. Dengan kriteria yang sama diharapkan memberikan hasil yang dapat dibandingkan secara objektif dan adil". Kriteria ukuran kinerja, menurut Amstrong dan Baron (2007:323) sebagaimana dikutip Wibowo, seharusnya: (1) Dikaitkan dengan tujuan strategis dan mengukur apa yang secara organisasional penting dan mendorong kinerja bisnis, (2) Relevan dengan sasaran dan akuntabilitas tim dan individu yang berkepentingan, (3) Memfokuskan pada output yang terukur dan penyelesaian tugas dan bagaimana orang bertindak dan bagaimana tingkah lakunya, (4) Mengindikasi data yang akan tersedia sebagai dasar pengukuran, (5) Dapat didiversifikasi dengan menguasakan informasi yang akan mengonfirmasi tingkat seberapa jauh harapan dapat dipenuhi, (6) Menjadi setepat mungkin dalam hubungan dengan maksud pengukuran dan ketersediaan data, (7) Mengusahakan dasar untuk umpan balik dan tindakan, dan (8) Bersifat komprehensif, mencakup 
semua aspek kinerja sehingga keluar ukuran tersedia.

Bagi Aguis (2009:120), "Kinerja dapat diidentifikasi dalam dua tipe perilaku atau faset kinerja yaitu : "task performance dan contekstual performance".

a. Kinerja tugas (task performance); yang dapat didefinisikan sebagai: (1) Aktivitas yang mengubah bahan-bahan mentah yang dihasilkan oleh organisasi, dan (2) Aktifitas yang membantu proses transformasi dengan mengisi pasokan bahan mentah, mendistribusikan produk yang telah selesai, atau menyediakan perencanaan penting, koordinasi, supervisi, atau fungsi-fungsi staf yang memungkinkan organisasi berfungsi secara efektif dan efesien.

b. Kinerja kontekstual (contekstual performance); yang dapat didefinisikan sebagai perilaku yang kontribusi pada efektifitas organisasi dengan menyediakan lingkungan yang baik dimana kinerja tugas dapat berlangsung. Kinerja kontekstual meliputi perilaku sebagai berikut: (1) Bertahan dengan antusiasme dan mengeluarkan upaya lebih sebagaimana yang diperlukan untuk menyelesaikan aktivitas tugas dengan sukses (seperti tepat waktu dan jarang absen, mengeluarkan upaya lebih pada pekerjaan); (2) Secara sukarela melakukan aktifitas-aktifitanya yang tidak secara formal menjadi bagian tugasnya (seperti menyarankan perbaikan organisasi, membuat saran-saran yang konstruktif); (3) Membantu dan bekerja sama dengan yang lain (seperti membantu menolong rekan kerja atau konsumen); (4) Mengikuti aturan dan prosedur organisasi (seperti mengikuti perintah dan peraturan, menunjukan hormat pada yang berwenang, mematuhi nilai dan kebijakan organisasi); (5) Mengusahakan, mendukung dan membela tujuan- tujuan organisasi (seperti loyalitas, menunjukan hal-hal yang baik terhadap pihak luar).

Dalam rangka mengetahui sejauh mana pencapaian kinerja dalam suatu organisasi biasanya dilakukan melalui kegiatan penilaian kinerja. Penilaian kinerja, menurut Dessler (2009:212), "evaluating an employee's current andor past performance relative to his or here performance standards". Batasan ini menjelaskan bahwa penilaian kinerja adalah evaluasi kinerja relatif pegawai saat ini dan atau yang telah berlalu terhadap standar kerjanya. Pengertian lain dikemukakan Hammer sebagaimana dikutip Schermerhorn, Hunt dan Osborn (2005:168) bahwa, "aprocess of systematically evaluating performance and providing feedback on which performance adjustments can be made". Definisi ini menunjukkan bahwa penilaian kinerja adalah suatu proses menilai kinerja secara sistematis dan memberikan umpan balik atas penilaian kinerja yang telah dibuat.

Dikatakan Newstrom (2007:138) bahwa filosofi penilaian kinerja modern menekankan pada kinerja dan tujuan mendatang.Filosofi modern juga menekankan pada partisipasi pegawai dalam mencapai tujuan yang telah ditetapkan bersama dengan supervisor serta hasil dari pengetahuan. Setidaknya ada lima filosofi dalam penilaian kinerja modern:

1) Performance orientation; it is not enough for employees to put forth effort; that effort must result in the attainment of desired outcomes (products or services) 
2) Focus on goals or objectives; employees need to have clear ideas of what they meant to do and prioritized from his duties;

3) Mutual goals setting between supervisor and employee; this is the belief that people will work harder for goals or objectives that they have participated in setting. Among their desires are to perform a wortwhile task, share in a group effort, share in setting their objectives, share in the rewards of their efforts, and continue personal growth.

4) Clarification of behavioral expectations; this is often done via a behaviorally anchored rating scale (BARS), which provides the employee and manager with concrete examples of various levels of behaviors. Brief descriptions of outstanding, very good, acceptable, below average, and unacceptable behaviors are specified for each major dimension of a job, thus cueing the employee in advance regarding the organization's expectations

Pengertian di atas dapat dijelaskan sebagai berikut:

1) Orientasi kinerja; tidak cukup bagi pegawai dengan hanya mengeluarkan upaya-upayanya. Upaya yang dilakukan harus menghasilkan pencapaian produk atau pelayanan yang dikehendaki.

2) Fokus pada tujuan dan sasaran; pegawai perlu memiliki ide-ide yang jelas dari apa yang mereka maksudkan untuk dilakukan dan diprioritaskan dari tugastugasnya.

3) Penetapan tujuan yang saling menguntungkan diantara supervisor dan pegawai; hal ini merupakan keyakinan bahwa orang bekerja lebih keras untuk pencapaian sasaran atau tujuan yangtelah dipartisipasinya dalam penetapan tujuan. Diantara keinginannya untuk melakukan tugas-tugas yang bermanfaat, bersama-sama dalam upaya kelompok, bersama dalam menetapkan tujuan, saling menghargai atas upaya yang dilakukan dan mengembangkanpribadi berkesinambungan.

4) Mengklarifikasikan perilaku yang diharapkan; hal ini sering dilakukan melalui skala rating jangkar perilaku (behaviorally anchored rating scale = BARS), yang memberikan pegawai dan pimpinan contoh konkrit dari tingkatan perilaku yang bervariasi. Tingkatan perilaku tersebut contohnya adalah sangat baik, dapat diterima, di bawah rata-rata, dan perilaku tidak dapat diterima yang secara khusus untuk masing-masing dimensi utama dari pekerjaan.

Mullins (2010:316) berpendapat tentang turnover, bahwa, "a frequent turnover of members is likely to have an adverse affect on morale and on the cohesiveness of the group". Seringnya anggota organisasi berniat turnover akan berdampak buruk bagi moral dan kohesivitas kelompok. Fishbeinm dan Ajzen (1975:288) mendefinisikan intensi sebagai berikut, "intention as person's location on a subjective probability dimension involving a relation between himself and some action. A behavior intention, therefore, refers to a person's subjective probability that he will perform some behavior.

Intensi adalah kemungkinan subyektif seseorang yang melibatkanhubungan antara dirinya dan suatu perbuatan tertentu. Sedangkan intensi seseorang untuk melakukan suatu perbuatan tertentu didefinisikan sebagai kemungkinan subyektif seseorang untuk melakukan perbuatan tertentu. Intensi ditandai dengan bagaimana 
upaya seseorang bertekat untuk mencoba dan berencana untuk menampilkan perilaku tertentu

Sebelum karyawan mengambil tindakan untuk mengeluarkan diri dari organisasi atau berhenti dari pekerjaannya, biasanya karyawan telah memikirkan dan mempertimbangkan hal tersebut sebelumnya.Niat atau intensi untuk mengeluarkan diri disebut intensi turnover yang merupakan hal yang mendahului terjadinya turnover secara sukrela karena karyawan sendiri yang berinisiatif untuk melakukan turnover.

Hal ini sejalan dengan pendapat Ajzen (2012:152) bahwa, "intentions to quit are defined as one as desire or willingness to leave an organization. The theory of reasoned action explains intentions as the mechanism that leads to the action of quitting." Niat untuk berhenti didefinisikan sebagai keinginan atau kemauan seseorang untuk meninggalkan suatu organisasi.Teori tentang tidakan rasional menjelaskan niat sebagai suatu mekanisme yang menuju pada tindakan untuk berhenti.

Intensi merupakan determinan atau penyebab langsung dari kebanyakan perilaku nyata. Intensi turnover merupakan pertanda awal terjadinya turnover karena terdapat hubungan yang signifikan antara intensi turnover dan turnover nyata. Intensi turnover dapat terjadi ketika karyawan melihat kesempatan lain yang lebih baik dari posisi yang ia miliki sekarang yang biasanya berkaitan dengan bayaran, karir, pengakuan, penghargaan yang lebih baik, lokasi dan lingkungan yag lebih nyaman, masalah kesehatan atau keluarga.

Sejalan dengan Kraut (2005:304) yang mengatakan bahwa, "individual turnover intentions can be described as a psychological response to specific organizational conditions, and fall along a continuum of organizational withdrawal behaviors ranging from day -dreaming to actual quitting. Intensi turnover seseorang dapat digambarkan sebagai respon psikologis terhadap kondisi tertentu dalam organisasi yang terjadi melalui perilaku menarik diri dari organisasi secara berkelanjutan mulai membayangkan hingga benar-benar berhenti.

Jacobs dalam Husain dan Asif (2012:04) mendefinisikan bahwa, "a turnover intention is a mental dicision previlailing between an individual's approach with reference to a job to continue or leave the job." Intensi turnover adalah keputusan yang berlaku dalam mental seseorang yang mengacu antara melanjutkan atau berhenti dari pekerjaaan.Intensi turnover merupakan hubungan singkat dari tindakan turnover. Sehingga perilaku turnovertidak dapat dipisahkan dan selalu diawali dengan intensi turnover

Pengertian Turnover menurut Kenichi (2002:24), "behavior of with drawing from an organizations that is perment, both voluntary and involuntary". Perilaku menarik diri dari organisasi yang bersifat permanen, baik itu secara sukarela maupun tidak suka rela. Hal tersebut sama halnya yang dikemukakan oleh robbins and judge (2009:63), "dismissal of employees divided into two types, namely voluntary turnover (voluntary turnover) and the type of employee who initiated the forced turnover (involuntary turnover) I initiatedby the company". Pemberhentian karyawan dibedakan menjadi dua tipe, yaitu 
turnover yang sukarela (voluntary turnover) yang diprakarsai karyawan dan tipe turnover yang terpaksa (involuntary turnover) yang diprakarsai oleh perusahaan.

Torington (2005:168) berpendapat bahwa, "turnover always rises when the economy is strong and jobs are plentiful because there are more opportunities available for people to change employers. Conversely, during recessions staff turnover falls because relatively few attractive permanent positions are advertised. Turnover selalu naik ketika perekonomian kuat dan pekerjaan yang berlimpah, karena adanya lebih banyak kesempatan yang tersedia bagi karyawan untuk berganti atasan.Sebaliknya, selama resesi pergantian staf menjadi rendah karena relative sedikit posisi permanen yang menarik untuk dipermosikan. Maksud dari pernyataan tersebut adalah tingkat turnover akan menjadi tinggi ketika terdapat banyak kesempatan untuk mendapatkan pekerjaan baru. Namun, pergantian karyawan akan menurun ketika terjadi resesi atau permasalahan dan kemunduran ekonomi.

Sedangkan Gray mendefenisikan, "turnover decision taken as a voluntary employee to leave the company where he work". Turnover sebagai keputusan yang diambil oleh seorang karyawan untuk meninggalkan perusahaan dimana dia bekerja. Dari WWW.Insightlink.com/article.html (diakses Desember 2016) Mobley (1986:122) menambahkan,"turnover has limitations, namely the cessation of individual members of organization with a financial reward by the organization concerned". Turnover memiliki batasan yaitu berhentinya individu dari anggota suatu organisasi disertai pemberian imbalan keuangan oleh organisasi yang bersangkutan

Ketdakhadiran menurut Jennifer (2012:94) dijelaskan, "absenteeism is a behavior that organizations can never eliminate, but they can control and manage it. Attendance policies should not be so restrictive, however, that they literally force employees to come to work even if they are ill". Ketidakhadiran adalah perilaku organisasi tidak pernah bisa hilang, tetapi mereka bisa mengendalikan dan mengolahnya.Kebijakan kehadiran tidak boleh dibatasi, namun bahwa mereka benar-benar memaksa karyawan untuk datang bekerja bahkan jika mereka sakit.)

Anderson (2001:233) mengungkapkan, "defines absenteeism as 'the failure to report for scheduledwork' Martocchio and Harrison (1993: 263) define it as 'an individual's lack of physical presence at a given location and time when there is a social expectation for him or her to be there.'thus, absence is the logical opposite of attendance". Ketidakhadiran didefenisikan sebagai kegagalan untuk melaporkan pekerjaan yang telah terjadwal.Ketidakhadiran juga didefenisikan sebagai kelemahan individu dalam hal kehadiran pada tempat dan waktu yang telah ditentukan di saat ada harapan sosial bahwamereka bisa hadir.Oleh karena itu, ketidakhadiran merupakan lawan dari kehadiran.

Lebih lanjut dijelaskan oleh Thomas (2011:146) bahwa, "absenteeism is important for both theoretical and practical reason. From a theoretical perspective, absenteeism represents a common way in which employees may withdraw from their jobs. From a practical perspective, absenteeism is a very costly problem to many organizations. When employees are absent, work may not get done or may be performed by less experienced employees" 
Dengan lebih seksama Cascio dan Boudreau (2011:58) menyebutkan, "absenteeism is any failureof an employee to report for or to remain at work as scheduled, regardless of reason." Dari pendapat ini disampaikan bahwa ketidakhadiran adalah kegagalan karyawan untuk melaporkan pekerjaannya atau tetap bekerja sesuai jadwal tanpa harus memperhatikan alasannya. Sekiranya cukup jelas bahwa Cascio dan Boudreau menjelaskan bahwa ketidakhadiran adalah bentuk kegagalan karyawan mematuhi jadwal kerjanya dan kegagalan untuk melaporkan apa yang seharusnya menjadi kewajibannya terhadap organisasi.

Selanjutnya, Fitz (2009:48) menulis, "absenteeism is an expense to the company, in that the work ascribed to a given job is not getting done by the person paid to do it when he or she is absent". Dalam tulisannya ini Fitz menjelaskan bahwa ketidakhadiran adalah beban bagi perusahaan. Ketidakhadiran ini dianggap berasal dari tugas yang dibebankan pada seseorang, namun tugas tersebut tidak dapat diselesaikan ketika orang tersebut tidak hadir.

Di samping itu Pilbeam dan Corbridge (2006:335) menyampaikan bahwa, "unauthorized absence or absenteeism can be defined as an occasion when an employee fails to report to work when contractually obliged to do so and without prior agreement for absent". Dari pendapat ini dijelaskan bahwa ketidakhadiran tanpa ijin atau ketidakhadiran didefenisikan sebagai suatu peristiwa ketika seorangkaryawan tidak melaporkan dirinya untuk tidak bekerja, pada saat terdapat kewajiban mengikat dan dilakukan tanpa persetujuan.

Selain itu menurut Douglas, "absenteeism means absence from work at the job at whick one is employed". Ketidakhadiran diartikan sebagai tidak hadir dari tempat kerja yang dilakukan oleh karyawan. Artinya seseorang tidak melaksanakan tugas tanpa ada surat pemberitahuan yang jelas sehingga pekerjaannya terbengkalai.

Http:// www.jstor.org/stable/2142029 (diakses 3 Januari 2017).

Menurut Kondalkar (2007:53), "absenteeismrefers to individual absenting himself from the jobor work place without any notice". Menjelaskan bahwa ketidakhadiran merujuk kepada ketidakhadiran seseorang pada pekerjaan atau pada tempat kerjanya tanpa memberikan keterangan.

Griffindan Moorhead (2006:01) menyebutkan, "absenteeism occurs when an employee does not show up for work." Disini dijelaskan bahwa ketidakhadiran terjadi ketika karyawan tidak masuk kerja. Dalam Human Resources and Personel Management dijelaskan, "absenteeism... the practiceof staying away from work for no good reason." Ketidakhadiran adalah praktek untuk menjauh dari pekerjaan dengan alasan yang tidak baik.

Griffin and Moorhead (2014:79) menyatakan, "some absenteeism has a legimatecause,such as illness, jury duty, or a death or illness in the family. At other times, the employee may report a feigned legitimate cause that's actually just an execuseto stay home. When an employee is absent,legitimately or not,her or hiswork does not get done at all or a substitutemust be hired to do it. In either case, the quantity or quality of actual outputis likely to suffer". Berdasarkan penjelasan di atas, ketidakhadiran terkadang dapat memiliki alasan sah seperti sakit, tugas, atau alasan karena ada anggota keluarga 
yang sakit.Namun terkadang seorang karyawan berpura-pura menggunakan alasan yang sah padahal karena dia ingin tinggal di rumah.Dengan kata lain ketidakhadiran dapat memiliki penyebab yang sah sehingga ketidakhadirannya dapat diterima organisasi tetapi karyawan juga dapat memanfaatkan alasan yang sah ini hanya untuk menghindari masuk kerja.

Perlu diperhatikan pula penjelasan George dan Jones (2012:85) bahwa, "absenteeismis a behavior that organizations can never eliminate, but they can control and manage it." Hal ini menegaskan bahwa ketidakhadiran adalah perilaku yang tidak akan bisa dihilangkan oleh organisasi, namun organsiasi mampu melakukan kontrol dan mengaturnya.

Ketidakhadiran adalah bentuk keniscayaan dalam sebuah organisasi. Oleh karena itu Organisasi harus mampu menjaring pimpinan yang memiliki kapabilitas dalam mengelola organisasi dengan baik. Sebagaimana yang di jelaskan dalam teori di atas bahwa sistem kontrol yang baik sangat dibutuhkan dalam sebuah organisasi dan hal tersebut hanya bisa terjadi apabila semua sistem kontrol di serahkan kepada orang-orang yang memiliki kapabilitas.

\section{METODE}

Penelitian ini dilaksanakan pada pegawai DinasPendidikan DKI Jakarta dilaksanakan selama 3 (tiga) bulan. Metode yang digunakan dalam penelitian ini adalah survey dengan menggunakan teknik kausal. Populasi adalah pegawai Dinas Pendidikan DKI Jakarta yang berjumlah 60 pegawai dengan jumlah sampel sebanyak 52 guru. Data yang dikumpulkan dalam penelitian dijaring melalui kuesioner yang berupa skala penilaian (rating scale) dengan sebaran skor antara 1 sampai dengan 5 .

Setelah dilakukan analisis deskriptif dilanjutkan dengan uji persyaratan analisis berupa uji normalitas, uji linearitas data dan keberartian regresi, dilakukan uji hipotesis dengan menggunakan teknik analisis jalur (path analysis).

\section{HASIL DAN PEMBAHASAN}

\section{Pengaruh langsung intensi turnover terhadap kinerja}

Hasil penelitan ini menunjukkan bahwa intensi turnover memberikan pengaruh positif secara langsung terhadap kinerja. Besarnya pengaruh tersebut ditunjukkan oleh koefisien korelasi -0,674 dan koefisien jalur -0,482. Hal ini menujukkan bahwa intensi turnover dapat menurunkan kinerja guru.

Hasil penelitian ini sejalan dengan pendapat John B. miner (2005:144) bahwa, "organizations with undesirably high turnover would do well to look into perceptions of pay equity and into the equitability of other aspects of the reward system. Thus, it appears that underreward inequity produces dissatisfaction, which, in turn, produces a number of possible consequences in addition to diminished performance". Organisasi yang mengalami tingkat intensi turnover yang tinggi cenderung melakukan perbaikan dengan menggunakan persepsi peningkatan dan pemerataan sistem pembayaran. Oleh karena ketimpangan tersebut akan mengakibatkan ketidakpuasan yang akan 
berdampak bukan hanya pada tataran kinerja pegawai, akan tetapi juga bisa berdampak pada aspek yang lain.

Lebih lanjut dijalaskan oleh John B. Mener (1999:64) bahwa, "objectives are based on what management wants accomplished or what is perceived to be necessary to achieve an adequate level of performance. Measures of turnover, absenteeism, job satisfaction, employee health, and compensation expenses are quantifiable and could be potential objectives for the HR function. However, these measures must be related to organization performance in order to represent meaningful approaches to reflect the HR contribution". Tujuan yang ingin dicapai oleh manajemen atau yang dibutuhkan dalam meningkatkan kinerja diantaranya turnover, absensi, kepuasan kerja, kesehatan pegawai dan biaya kompensasi yang terukur serta mampu mencapi tujuan secara potensial dalam tataran fungsi $\mathrm{HR}$. namun langkah tersebut harus bersinergi dengan kinerja organisasi yang mencerminkan kontribusi HR.

Menurut Schermerhorn (2005:390) bahwa, "absenteeism and turnover are costly in terms of the recruitment and training needed to replace workers, as well as in the productivity lost while new workers are learning how to perform up to expectations". Ketidakhadiran dan turnover sangat merugikan lembaga. Untuk mengganti pegawai yang menarik diri maka lembaga akan melakukan rekruitmen dan pelatihan untuk mengganti pekerja yang produktif serta pegawai baru harus dilatih sedemikian rupa bagaimana melakukan kinerja yang baik dami mencapai tujuan yang diharapkan.

\section{Pengaruh langsung ketidakhadiran terhadap kinerja}

Hasil penelitan ini menunjukkan bahwa ketidakhadiran memberikan pengaruh positif secara langsung terhadap kinerja. Besarnya pengaruh tersebut ditunjukkan oleh koefisien korelasi -0,610 dan koefisien jalur -0,331.

Hasil penelitian ini sejalan dengan pendapat Benjamin et, el (1999:60-61) bahwa, "on a broader scale, another study assessed the effects of several variables on organizational performance involving 25 manufacturing plants in one company.' $y$ The study linked the attitudinal climate, absenteeism rate. grievance rate. disciplinary action rate, and overtime ratio to two measures of organizational performance: direct labor efficiency and quality of product. Each measure was significantly related to organizational performance except that absentee rate was not related to the quality of product".

Dalam skala yang lebih luas, studi lain yang menilai efek kinerja organisasi yang melibatkan 25 pabrik di salah satu perusahaan. Penelitian yang dilakukan terkait iklim, sikap, tingkat absensi, keluhan, tindakan disipliner dan rasio lembur dalam tataran kinerja organisasi. Setiap tindakan secara signifikan berhubungan dengan kinerja organisasi kecuali tingkat absensi

Penelitian di atas menunjukkan bahwa kinerja secara signifikan berhubungan dengan sikap, iklim kerja, disiplin dan rasio lembur, akan tetapi absensi akan berdampak lain terhadap lembaga dan akan semakin buruk apabila tidak mendapatkan perhatian yang lebih dari pimpinan lembaga.

Lain halnya dengan Luthan (2011:133) yang menjalaskan bahwa, "a large study including participants from several European countries, many occupational groups, 
and multiple methods of measuring performance found both conscientiousness and emotional stability related to all the measures and occupations.62 Yet, the absenteeism study found that conscientiousness had a desirable inverse relationship". Sebuah studi besar yang pesertanya termasuk beberapa Negara Eropa menyatakan bahwa banyak metode yang dapat dilakukan dalam mengukur kinerja diantara kesadaran dan stabilitas emosional, namun dalam studi tentang absensi menemukan bahwa kesadaran memiliki hubungan terbailik dengan apa yang diharapkan. Artinya dalam aspek lain studi tentang ketidakhadiran juga berpengaruh terhadap metode pengukuran kinerja, oleh karena itu teori lebih memperjelas bahwa pengaruh ketidakhadiran bukan hanya pada satu aspek tindakan akan tetapi juga mempengaruhi aspek yang lain.

Lebih lanjut Robbins (2009:10) menjelaskan bahwa, "organizatioal Behavior is concerned specifically with employment-related situations, you should not be surprised that it emphasizes behavior as related to concerns such as jobs, work, absenteeism, employment turnover, productivity, human performance, and management". Perilaku organisasi sangat berkaitan dengan situasi yang berhubungan dengan pekerjaan, pegawai tidak perlu heran bahwa perilaku organisasi menekankan pada aspek perilaku yang terkait dengan kekhawatiran seperti pekerjaan - pekerjaan, absensi, turnover tenaga kerja, produktivitas, kinerja manusia, dan manajemen. Artinya dalam perilaku organisasi selalu mengarah pada perilaku seseorang seperti absensi, turnover, produktivitas dan kinerja. Hal tersebut dapat mengindikasikan absensi dan produktivitas saling mempengaruh namun labih jelasnya ketidakhadiran akan secara signifikan berpengaruh terhadap kinerja.

\section{Pengaruh langsung intensi turnover terhadap ketidakhadiran}

Hasil penelitan ini menunjukkan bahwa intensi turnover memberikan pengaruh positif secara langsung terhadap ketidakhadiran. Besarnya pengaruh tersebut ditunjukkan oleh koefisien korelasi 0,580 dan koefisien jalur 0,580.

Hasil penelitian ini sejalan dengan pendapat John a. Wagner (2010:110) bahwa, "the source of indirect costs - most notably in the form of absenteeism and turnover. Dissatisfaction is a major reason for absenteeism, an organizational". Sumber yang tidak langsung bisa dalam bentuk absensi dan juga bisa dalam bentuk turnover. Ketidakpuasan merupakan alasan utama untuk tidak hadir ke tempat kerja. Artinya bahwa apabila pegawai mengalami ketidakpuasan maka akan berdampak pada keinginan untuk keluar dari tempat dia bekerja. Jika keinginan untuk keluar dari tempat kerjanya sudah sedemikian rumitnya maka akan berakibat pada keinginan pegawai untuk menunda-nunda masuk kerja atau bahkan absen dari tempat kerja.

Banyak hal yang dapat berpengaruh terhadap ketidakhadiran pegawai atau absen dari tempat kerja. Saat pegawai tidak mampu mengotrol diri serta tidak mampu menyelesaikan persoalan dengan baik akan segala sesuatu akan berdampak pada aspek yang lain sebagaimana yang disebutkan oleh Luthan (2011:45) bahwa, "for both man and women, work to family conflict was found to be linked to job satisfaction, turnover intention dan stress, while family to work conflict resulted in stress and absentee 
in". Baik pria maupun wanita konflik yang dialami dalam keluarga sangat mempengaruhi tingkat kepuasan kerja juga dapat mengalihkan perhatian dan menjadi stres, sementara bekerja dalam suasan konflik justru mengakibatkan stres dan ketidakhadiran. Artinya banyak hal yang bisa memicu terjadinya ketidahadiran pegawai dari tempat kerja mulai dari konflik antar pegawai maupun pimpinan, ketidakpuasan kerja, keinginan untuk pindah kerja dan bahkan karena stres sehingga mereka malas atau tidak perduli terhadap pekerjaannya.

Menurut Robbins (2009:27) bahwa, "there are many forms of withdrawal ranging from showing up late or failing to attend meetings to absenteeism and turnover". Banyak bentuk penarikan diri yang dilakukan oleh pegawai dalam sebuah lembaga mulai dari muncul terlambat atau gagal dalam menghadiri pertemuan, absensi dan turnover. Artinya jika pegawai sudah berniat keluar dari tempat kerja maka banyak hal di luar kebiasaannya dapat dilakukan terlambat masuk kerja ataupun absen masuk kerja

\section{PENUTUP}

Kesimpulan: (1) Turnover berpengaruh langsung negatif terhadap kinerja pegawai. Artinya, semakin tinggi tingkat turnover pegawai maka akan semakin rendah kinerja pegawai Dinas Pendidikan DKI Jakarta. (2) Ketidakhadiran berpengaruh langsung negatif terhadap kinerja pegawai. Artinya, semakin tinggi ketidakhadiran maka akan mengakibatkan penurunan kinerja pegawai Dinas Pendidikan DKI Jakarta. (3) Turnover berpengaruh langsung positif terhadap ketidakhadiran pegawai. Artinya, semakin tinggi tingkat turnover mengakibatkan peningkatan ketidakhadiran pegawai Dinas Pendidikan DKI Jakarta.

Saran: saran - saran untuk guru. diharapkan dapat menurunkan turnover agar dapat meningkatkan kinerja adalah: 1) keikhlasan pegawai dalam melaksanakn tugas yang di embannya, 2) Senantiasa bersikap santun terhadap sesama maupun pimpinan, 3) mampu mengotrol diri dalam mengatasi permasalahan yang ada, menjaga stabilitas emosional dalam menjaga kestabilan dan kenyamanan.

Kedua, saran untuk guru terkait dengan ketidakhadiran agar meningkatkan kinerja adalah: 1) pegawai harus mengedepankan kepentingan lembaga, 2) aktif dalam menyukseskan program sekolah, 3) memberikan keyakinan kepada diri bahwa melaksanakan tugas adalah kebutuhan bukan kewajiban.

\section{DAFTAR RUJUKAN}

Adrian Wikinson \& Torn Redman, Cotemporary Humam Reasoure Management, Text and Cases. New York: Prentice Hall, 2003.

Anuradha Sharma, Management and Job Performance. Delhi: Gian Publishing House, 2008. 
A. Kinichi and R. Kreitner, Organizational Behavior, Key Concept, Skill and Best Practices. New York: McGraw-Hiil, 2003.

AC Fitz, The ROI of Human Capital: Measuring the Economic Value of Emloyee Perfomance, $2^{\text {nd }}$ Edition. New York: AMACOM, 2009.

A. Ivanovic, dan P.H. Collin, Dictionary of Human Resources and Personnel Management

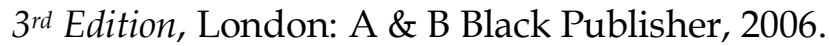

Chieh-Peng Lin, dan Cheng G. Ding, "Moderating Effect of The Locus of Control on The Process of Turnover Intentios for High-Tech-Personnel" Asia Pacific Manajemenr Review Vol. 10, 2005.

E.K Laitinen, " A dynamic performance measurement system: evidence form small Finnish tecnology companies, "Scandinavian Journal of Management, Vol. 18 No. 2, 2002.

Ellen F. Jackofsky Turnover and Job Performance: An Integrated Process Model January 1, 1984 vol. 9 no. 1 74-83

Falconi, Robert R, Tumover Can be Good, Journal World Executive's Digest htttp://search.proquest.com/docview/20164910?accountid=33269(diakses Desember 2016).

Fred Luthans, Organizational Behavior: An evidence-Based Approach $12^{\text {th }}$ Edition, New York: McGraw-Hill/Irwin, 2011.

Gary Desller,Manajemen SumberDaya Manusia, Jilid 1. Jakarta: Indkes, 2006.

Gary Dessler, Fundamental of Human Resources Management: Content, Competencies and Aplications. New Jersey: Pearson Education, Inc., 2009.

Herman Aguis, Performance Management . New Jersey: Pearson Education, Inc., 2009.

Hendry S. Manejemen sumber Daya Manusia. Yogyakarta:Stie YKPN, 2004.

Ivancevich, John M. Organizational Behavior and Management International Ed. New York: MGraw-Hill, 2008.

Jack J.Phillips. Accountability In Human Resource Management. New York: Butterworth-Heinemann 1999. 
Jennifer M. George dan Gareth R. Jones, Understanding and Managing Organizational Behavior $6^{\text {th }}$ Edition, New Jersey: Pearson Education, 2012.

Johnson Emily Catherine, A Multi Level Investigation of Overall Jop Performance Ratings. Partkway: ProQuest LLC, 2009.

John Benardin, Humam Reasorce Management. New York: McGraw- Hill Irwin, 2007.

John R. Schermerhon, Jr, James G Hunt dan Richard N. Osborn, Organizational Behavior. New Jessey: John Willey \& Sons, Inc., 2005.

John W. Newstorom, Organizational Behavior: Humam Behavior at Work. New York: McGraw- Hill, 2007.

------, Organizational Behavior; Human Behavior at Work 13th. New York; McGrawHill,2011.

John B. Miner-Organizational Behavior I_ Essential Theories Of Motivation And Leadership-M.E. Sharpe. New York: 2005.

John A. Wagner dan John R. Hollenbeck. Organizational Behavior . New York: Taylor and frances group, 2010.

Michael Armstrong, A Handbook Of Human Resource Management Practice A Handbook Of 10th Edition. London and Philadelphia: Kopan Page, 2006.

Neil Anderson et.al, Handbook of Industrial: Work and Organizational Psychology, London: SAGE Publications, 2001.

R.D Gray, Exist Interview and Employee Turnover, WWW.Insightlink.com/article.html (diakses Desember 2016)

Robert J. Greene. Rewarding Performance; Guiding Principles; Custom Strategi. New York: First Published, 2011.

Ricky W. Griffin dan Gregory Moorhead, Organizational Behavior: Managing People and Organizations 11 th Edition, Mason: Cengage Learning, 2014.

Robert. L. Mathis and John Jackson, Human Resources Management $13^{\text {th }}$ South_Western, Cengage Learning, 2011. 